\title{
Distribution and morphology of colorless sulfur bacterium of the genus Thiothrix in water reservoirs of Baikal rift zone
}

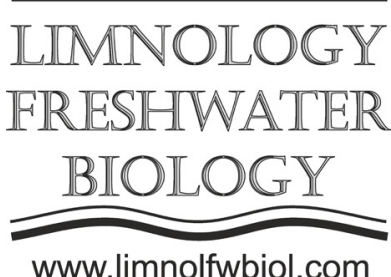

\author{
Chernitsyna S.M. ${ }^{1 *}$, Khalzov I.A. ${ }^{1}$, Pogodaeva T.V. ${ }^{1}$, Barkhutova D.D. ${ }^{2}$, \\ Lavrentieva E.V. ${ }^{2}$, Zemskaya T.I. ${ }^{1}$ \\ ${ }^{1}$ Limnological Institute, Siberian Branch of the Russian Academy of Sciences, Ulan-Batorskaya Str., 3, Irkutsk, 664033, Russia \\ ${ }^{2}$ Institute of General and Experimental Biology, Siberian Branch of the Russian Academy of Sciences, Sakhiaynovoi Str., 6, Ulan-Ude, \\ 670047, Russia
}

\begin{abstract}
The habitats of colorless sulfur bacteria of the genus Thiothrix have been investigated in 7 hot springs of the Baikal rift zone. The intensity of their development depended on the distance from the outlet of thermal water to the surface and the flow rate of water. The most massive fouling of Thiothrix was observed at the border of mixing thermal and river water (Umhei, Alla). Slight Thiothrix fouling was observed at a significant distance from the thermal water outlet of the Goryachinsk spring.
\end{abstract}

Keywords: colorless sulfur bacteria, Thiothrix

\section{Introduction}

In the Baikal rift zone, there are a large number of hot springs (Borisenko and Zamana, 1978), where colorless sulfur bacteria live. In Lake Baikal, they are found in sites with an increased content of organic matter and intensive processes of sulfate reduction and methane generation (Namsaraev and Zemskaya, 2000). Sulfur bacteria of the genera Thioploca and Thiothrix have been identified in the lake. Thioploca is widespread throughout the lake (Namsaraev et al., 1994; Zemskaya et al., 2009). Thiothrix forms extensive white mats in the coastal zone in bay Zmeevaya (Chernitsyna et al., 2019) and hot spring Kotelnikovskii (Kompantseva and Gorlenko, 1988). In the Barguzin valley, bacteria of the genus Thiothrix were found in hot springs Khoito-Gol (Tatarinov et al., 2010), Seya, Alla and Bolsherechenskii (Namsaraev, 2003).

The purpose of this study was to determine the distribution of the colorless sulfur bacterium of Thiothrix genus and its morphological characteristics in hot springs which differing by physicochemical parameters.

\section{Material and methods}

Thiothrix (white fouling) were sampled during 2019-2020 in hot springs: Zmeevii, Kotelnikovskii, Davsha (Baikal coast), Umhei, Alla, Kuchiger, Goryachinsk (Barguzinskaya valley) (Fig., Table 1). Physicochemical characteristics were measured at the outlet of hot water and at the development sites of
Thiothrix (ProfLine pH 3310, Germany; Table 2).

Photos of Thiothrix were done using Axiovert 200 microscope (Zeiss, Germany). Also samples were stained with DAFI $(10 \mu \mathrm{g} / \mathrm{ml})$, washed with phosphate buffer $(0,1 \mathrm{M})$ and fixed in a $4 \%$ formaldehyde solution. Samples were viewed on a scanning laser confocal microscope LSM-710 (Carl Zeiss, Germany) in the CIC "Ultramicroanalysis".

Anion concentrations were measured by means of liquid chromatography, on a Milichrom-2A chromatograph with a relative error of 5-10\% (Baram et al., 1999). The samples for cation analysis were stored in polystyrene vials pre-acidified with $50 \mu \mathrm{L}$ of ultrapure concentrated $\mathrm{HNO}_{3}$ and stored at $4{ }^{\circ} \mathrm{C}$ prior to analysis. Cation $\left(\mathrm{Ca}^{2+}, \mathrm{Mg}^{2+}\right)$ concentrations were determined by means of atomic absorption on an AAS30 Carl Zeiss Jena spectrophotometer, as well as by flame emission methods (for $\mathrm{Na}^{+}$and $\mathrm{K}^{+}$; Fomin, 2000) with a relative error of $3-5 \%$ (Table 2 ).

\section{Results and discussion}

Bacterial foiling of Thiothrix cover plants, stones and are found on animals in the coastal zone of bay Zmeevaya. There are no visible Thiothrix foiling in baths at high temperatures; Thiothrix flocs of different density were found along the coast at a distance of up to $2 \mathrm{~m}$ from the bank line.

In the other hot springs, sulfur colorless bacteria are also found on stones and plants in the zone where there is a stream of water, that, in our opinion, provides oxygen access. This can be seen in Goryachinsk spring, 
Table 1. Chemical characteristics of thermal waters of studied springs (Borisenko and Zamana, 1978; Namsaraev et al., 2007; own data).

\begin{tabular}{|c|c|c|c|c|c|c|c|c|}
\hline \multirow[t]{2}{*}{ spring } & \multicolumn{3}{|c|}{ outlet } & \multicolumn{3}{|c|}{ mat of Thiothrix } & \multirow{2}{*}{$\begin{array}{c}\text { miner- } \\
\text { aliza- } \\
\text { tion, g/1 }\end{array}$} & \multirow[t]{2}{*}{ Characteristics of water } \\
\hline & $\mathrm{T},{ }^{0} \mathrm{C}$ & $\mathrm{pH}$ & Eh, mV & $\mathrm{T},{ }^{0} \mathrm{C}$ & $\mathrm{pH}$ & Eh, mV & & \\
\hline Zmevii & 45 & 9.6 & -441 & 18.0 & 8.3 & -231 & 0.477 & $\begin{array}{l}\text { hydrocarbonate-sulfate-sodium, } \\
\text { Ra, } \mathrm{H}_{2} \mathrm{~S}, \mathrm{CH}_{4}, \mathrm{~N}_{2} \text {, silicic acid }\end{array}$ \\
\hline Kotelnikovskii & $60-80$ & 9.2 & -137 & 32 & 9.5 & -120 & 0.32 & $\begin{array}{l}\text { fluorid-hydrocarbonate- sodium, } \\
\qquad \mathrm{Ra}, \mathrm{H}_{2} \mathrm{~S}\end{array}$ \\
\hline Davsha & 40 & 9.2 & -67 & 33.5 & 9.2 & +4.6 & 0.46 & $\begin{array}{l}\text { chloride-sulfate-sodium, silicic } \\
\text { acid, } \mathrm{N}_{2}, \mathrm{~F}\end{array}$ \\
\hline Kuchiger & 47 & 9.7 & -380 & 37.5 & 9.47 & -350 & 0.3 & $\begin{array}{l}\text { fluorid-hydrocarbonate-sulfate, } \\
\text { Ra, } \mathrm{H}_{2} \mathrm{~S} \text {, silicic acid }\end{array}$ \\
\hline Alla & $54 \div 73$ & 9.7 & -446 & 22.1 & 8.8 & -258 & 0.3 & $\begin{array}{l}\text { sulfate-hydrocarbonate sodium, } \\
\qquad \mathrm{H}_{2} \mathrm{~S}, \mathrm{~N}_{2}\end{array}$ \\
\hline Umhei & 44 & 9.6 & -388 & $15 \div 19$ & $8.6-9.0$ & $-274 \div-185$ & 0.36 & $\begin{array}{l}\text { fluorid-hydrocarbonate-sulfate, } \\
\qquad \mathrm{Ra}, \mathrm{H}_{2} \mathrm{~S}\end{array}$ \\
\hline Goryachinsk & 51.4 & 9.0 & - & 19.2 & 7.3 & -292 & 0.53 & $\begin{array}{c}\text { carbonate-sulfate-sodium, } \mathrm{H}_{2} \mathrm{~S}, \\
\text { silicic acid }\end{array}$ \\
\hline
\end{tabular}

where Thiothrix fouling is found at a significant distance from the outlet of thermal water from the ground (after the pond), in a site where the water temperature decreased to $18^{\circ} \mathrm{C}$, but there is a water current. No fouling of sulfur bacteria was visually detected in the stagnant pond formed by the thermal water. Probably, low water temperature and distance from the outlet also affects the morphology of bacteria: in this area Thiothrix is represented by the smallest sizes of flocs.

\section{Conclusions}

Colorless sulfur bacteria are involved in the accumulation and crystallization of sulfur and play an important role in the ecosystem, since at night the oxidation of sulfur compounds is the main point of oxygen consumption (Zavarzin, 2003). Various researchers have suggested that these bacteria protect organisms (for example, plants, small animals) from the

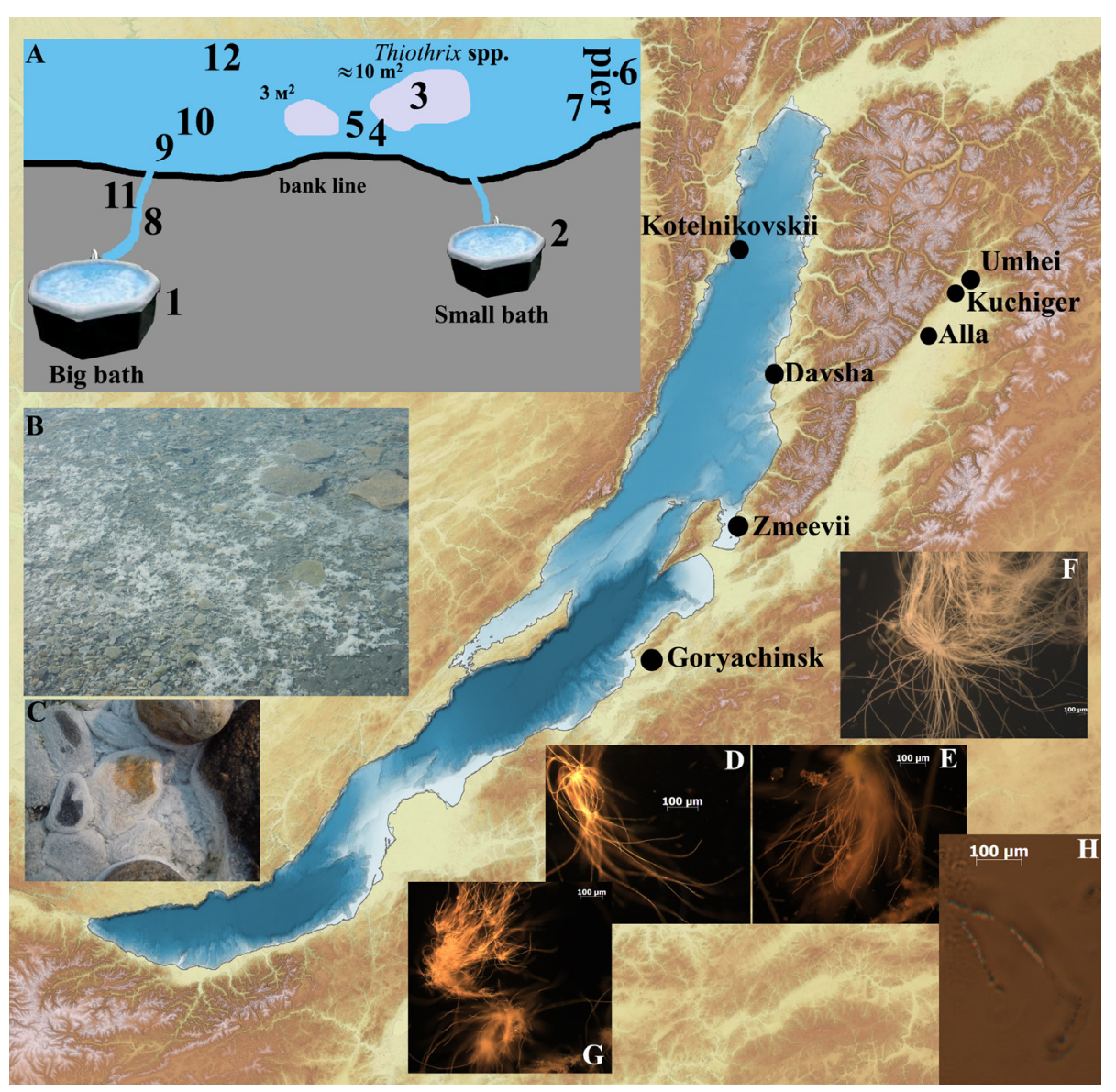

Fig. Schematic map of the locality of sampling stations (map - ASTER GDEM (v.2) and INTAS Project 99-1669 Team). A schematic map of sampling in bay Zmeevaya. B, C - foiling on stones in Zmeevaya bay and Umhei spring, respectively. View of Thiothrix (10x): D - Alla, E - Goryachinsk, F - Umhei, G - Kuchiger, H - Alla (100x). 
Table 2. Physical and chemical profiles of water in Zmeevaya bay (concentration of ion - $\mathrm{mg} / \mathrm{l}$ ).

\begin{tabular}{|c|c|c|c|c|c|c|c|c|c|c|c|c|}
\hline site & $\mathrm{T},{ }^{\circ} \mathrm{C}$ & $\mathrm{pH}$ & $\mathrm{Eh}, \mathrm{MB}$ & $\mathrm{HCO}_{3}^{-}$ & $\mathrm{Cl}^{-}$ & $\mathrm{NO}_{3}^{-}$ & $\mathrm{SO}_{4}^{2-}$ & $\mathrm{Na}^{+}$ & $\mathrm{K}^{+}$ & $\mathrm{Ca}^{2+}$ & $\mathrm{Mg}^{2+}$ & $\mathrm{NH}_{4}^{+}$ \\
\hline 1 & 42.6 & 9.6 & -441 & 3280 & 16.2 & 10.9 & 92 & - & - & - & - & - \\
2 & 39.0 & 9.2 & -442.6 & 3078 & 13.0 & 7.9 & 76 & - & - & - & - & - \\
3 & 18.8 & 8.5 & -230 & 47.2 & 0.51 & 0.14 & 8.90 & 2.50 & 0.90 & 13.1 & 0.98 & 0.06 \\
4 & 18.5 & 8.4 & -152.7 & 81.3 & 0.35 & 0.06 & 6.86 & 4.70 & 0.60 & 20.0 & 1.36 & 0.06 \\
5 & 19.4 & 8.9 & -198.8 & 75.7 & 21.4 & 0.00 & 60.9 & 40.9 & 1.20 & 18.8 & 0.61 & 0.34 \\
6 & 23.8 & 9.1 & -420 & 71.9 & 5.48 & 0.00 & 7.06 & 15.0 & 1.20 & 11.5 & 1.90 & 0.22 \\
7 & 18.0 & 8.3 & -231 & 59.0 & 3.71 & 0.19 & 16.2 & 2.60 & 0.70 & 20.5 & 1.23 & 0.10 \\
8 & 32.9 & 9.6 & -360 & 84.1 & 27.8 & 0.00 & 60.5 & 51.7 & 1.20 & 16.1 & 0.05 & 0.14 \\
9 & 21.6 & 9.0 & -285 & 86.4 & 14.8 & 0.00 & 43.6 & 36.4 & 2.80 & 15.2 & 0.98 & 0.26 \\
10 & 19.9 & 8.9 & -210 & 70.1 & 0.27 & 0.13 & 5.22 & 2.90 & 1.30 & 17.9 & 1.35 & 0.06 \\
11 & 32.3 & 9.6 & -426 & - & - & - & - & - & - & - & - & - \\
12 & 19.1 & 7.8 & +150 & 69.0 & 0.26 & 0.00 & 5.21 & 3.40 & 1.00 & 16.3 & 2.98 & 0.01 \\
\hline
\end{tabular}

aggressive action of hydrogen sulfide. Thus, the sulfideoxidizing Beggiatoa protects the rhizosphere of rice plants from the toxic effect of sulfide (Joshi and Hollis, 1977). However, by covering plants with a dense layer, sulfur bacteria can prevent photosynthesis.

At present time we analyze microbiomes of Thiothrix fouling from all hot springs. To clarify the phylogenetic position and determine metabolism in sulfur, nitrogen and carbon cycles, full-genome studies of Thiothrix from the water reservoirs of the Baikal rift zone are planned in the future.

\section{Acknowledgements}

This work was conducted within the framework of the State Task (project No. 0345-2019-0007 (AAAA-A16-116122110064-7). This study was carried out using computational resources of the HPC-cluster «Akademik V.M. Matrosov» of Irkutsk Supercomputer Center of SB RAS and equipment of Core Centrum 'Genomic Technologies, Proteomics and Cell Biology' in ARRIAM.

\section{References}

Baram G.I., Vereshagin A.L., Golobokova L.P. 1999. Application of high-efficiency microcolumn liquid chromatography with UV detection for determining anions in environmental objects. Zhurnal Analiticheskoy Khimii [Journal of Analitical Chemistry] 54(9): 962-965. (in Russian)

Borisenko I.M., Zamana L.V. 1978. Mineral'nyye vody Buryatskoy ASSR [Mineral waters of the Buryat ASSR]. Ulan-Ude: Buryat Press. (in Russian)

Chernitsyna S.M., Pogodaeva T.V., Dul'tseva N.M. et al. 2019. Microbial community in the area of hot hydrogen sulfide spring in Zmeevaya bay, Lake Baikal. In: All-Russian Conference with International Participation "Mechanisms of Adaptation of Microorganisms to Various Habitat Conditions", pp. 98-101. (in Russian)

Fomin G.S. 2000. Voda. Kontrol' khimicheskoy, bakteriologicheskoy i radiatsionnoy bezopasnosti po mezhdunarodnym standartam [Water. Control of chemical, bacteriological and radiation safety according to international standards]. Moscow: Protector. (in Russian)

Joshi M.M., Hollis J.P. 1977. Interaction of Beggiatoa and rice plant: detoxification of hydrogen sulfide in the rice rhizosphere. Science 195(4274): 179-180. DOI: 10.1126/ science.195.4274.179

Kompantseva E.I., Gorlenko V.M. 1988. Phototrophic communities in some thermal springs of Lake Baikal. Microbiology (Microbiologiya) 57(5): 841-856. (in Russian)

Namsaraev B.B., Dulov L.E., Dubinina G.A. et al. 1994. Participation of bacteria in organic degradation processes in microbial mats of Lake Baikal. Microbiology (Microbiologiya) 63(2): 344-351. (in Russian)

Namsaraev B.B., Hahinov V.V., Garmaev E.G. et al. 2007. Vodnyye sistemy Barguzinskoy kotloviny [Water systems of Barguzinsky Basin]. Ulan-Ude: Press of BSU. (in Russian)

Namsaraev Z.B. 2003. Microbial communities of alkaline thermal springs. Cand. Sc. Dissertation, Institute of Micobiology RAS, Moscow, Russia. (in Russian)

Namsaraev B.B.,ZemskayaT.I. 2000. Mikrobiologicheskiye protsessy krugovorota ugleroda $\mathrm{v}$ donnykh osadkakh ozera Baikal [Microbiological processes of carbon cycle in the bottom sediments of Lake Baikal]. Novosibirsk: Press SB RAS, Geo. (in Russian)

Tatarinov A.V., Danilova E.V., Yalovik L.I. et al. 2010. Bacterial communities in Hoito Gol hot spring, eastern Sayan, and the ecologic-geological conditions of their development. Geochemistry International 48(2): 152-162. DOI: 10.1134/ S0016702910020047

Zavarzin G.A. 2003. Lektsii po prirodovedcheskoy mikrobiologii [Lectures on natural history microbiology]. Moscow: Nauka. (in Russian)

Zemskaya T.I., Chernitsyna S.M., Dul'tseva N.M. et al. 2009. Colorless sulfur bacteria Thioploca from different sites in Lake Baikal. Microbiology (Microbiologiya) 78(1): 134-143. DOI: 10.1134/S0026261709010159 